\title{
Estimation of Some Immunological Markers of Iraqi Patients in Systemic Lupus Erythematosus with Lupus Nephritis
}

\author{
Noor Alhuda Kh. Ibrahim ${ }^{1}$, Ali Abdulmajid Dyab Allawi², \\ Kadhim K. Ghudhaib ${ }^{3}$, Faten Abdulghani Hammoudi ${ }^{4}$ \\ ${ }^{1}$ Post Graduate in Department of Chemistry, College of Science for Women, University of Baghdad, Baghdad- \\ Iraq, ${ }^{2}$ Professor, FRCP London, Consultant Transplant Nephrologist in Baghdad College of Medicine, University \\ of Baghdad, Baghdad, Iraq, ${ }^{3}$ Assistant Professor in Department of Chemistry, College of Science for Women, \\ University of Baghdad, Baghdad-Iraq, ${ }^{4}$ Specialist in Diagnostic Laboratory, Baghdad-Iraq
}

\begin{abstract}
Background: The chronic autoimmune inflammatory, systemic lupus erythematosus (SLE), is a disease that may be caused by autoantibody production, complement activation, and immune complex deposition. Several organs can be affected by this disease; lupus nephritis which considers the most complication that may be occurred. The aim of our study is to establishif that serum sVCAM-1 and IL-18 can be applied as biomarker for diagnosis of LN and CKD in patients with SLE.

Method: One hundred twenty patients from both sexes were enrolled in this study. The subjects have been divided into three groups, group one and group two represent the patient groups that include, (40) patients SLE with LN (8 male-32 female) with age range (19-44) years for the group one, (40) patients SLE without LN with age range (16-45), for the group two. The third group includes (40) healthy subjects with age range (19-62) years, which represent the control group. VCAM-1 and IL-18, were estimated by ELISA method.

Results: The results referred to present high level of VCAM-1 and IL-18 in patients group that represent a complication case of SLE in comparison with patients group without complication " without LN". At the same time, the results showed significance increasing of VCAM-1 and IL-18 in both patients groups rather than control group. Also, this study revealed a significant correlation $(\mathrm{p}<0.01)$ between VCAM-1 and IL-18, but no correlation with other relevant factors.

Conclusion: The results revealed the elevation of both SVCAM-1 and IL-18 levels in patients with SLE. Furthermore, this study indicates the association between the mentioned biochemical factors and suggests being as a useful indicators for LN in patients with SLE.
\end{abstract}

Keywords: SLE, VCAM-1, IL-18, LN; Iraqi Patients.

\section{Introduction}

Complications of SLE include a wide range of disorders for numerous organs. Lupus nephritis

\section{Corresponding Author:}

\section{Noor Alhuda Kh. Ibrahim}

Post Graduate in Department of Chemistry, College of Science for Women, University of Baghdad, BaghdadIraq

e-mail: nooralaazawi80@gmail.com considers the main disease that may be occurred as a result of action $\mathrm{SLE}^{(1)}$. Chronic inflammation were investigated in many cases in previous our studies ${ }^{(2,3)}$. The facilities of cell adhesion molecules (CAM) include adherence of leukocyte and control their movement into inflame tissues ${ }^{(4)}$.

Leukocyte circulation and lymphoid cells can be adjusted and allowed to adhesion on specific tissues or inflammation sites by vascular cell adhesion molecule-1 (VCAM-1). There are three types of adhesion molecules that include: integrins selectins ${ }^{(5)}$ and immunoglobulin 
supergene family (IGSF). The molecule-1 (ICAM-1) and the molecule-1 (VCAM-1) of vascular cell adhesion belong to the supergene family of immunoglobulins (IGSF), they are response for many cytokines such as IL-1 and TNF. Soluble forms of these moleculesare discarding from endothelial cell surfaces and are easily measurable in serum ${ }^{(6)}$. At the same time, these soluble forms represent the most abundant of the circulating adhesion molecules at maximum dissimilarity levels with numerous inflammatory disorders. The highest level of these soluble adhesion molecules is found in patients with SLE and rheumatoid arthritis in comparison with healthy subjects ${ }^{(7)}$. On another hand, levels of SVCAM-1 have been found to associate with the activity of inflammation disease as in SLE rather than other soluble adhesion molecules Several studies were proposed that urinary sVCAM-1 useful as a good marker for inflammatory diseases ${ }^{(8)}$.

Dendritic cells and macrophages consider the main source to produce IL- $1 \alpha$ IL-B and IL-18, which belong to Interleukin-1 family cytokines . Furthermore IL18 involved in pathogenesis of inflammatory disease, thus, it becomes of importance in association with a wide range of inflammatory diseases especially SLE. ${ }^{(9)}$ Previous studies referred to that, the exogenous IL-18 mice administration increased the incidence of sickness and nephritis, while IL-18 decreased improved survival and proteinure in the mice rather than in the healthy community. Moreover, few studies were revealed that IL-18 level increase in patients with SLE .Furthermore, the association between severity disease and IL-18 was confirmed $^{(10)}$.

\section{Subjects and Method}

One hundred and twenty patients from both genders who attended Baghdad Teaching Hospital/Medical City Iraq from December 2018 to May 2019 were involved in this study. The subjects have been grouped into three categories: forty SLE patients with LN (8 male-32 female) with age range (19-44) years, forty SLE patients without $\mathrm{LN}$, age range (16-45) and forty healthy subjects with age range (19-62) years.

Patients with SLE (without renal involvement) were clinically diagnosed with examination markers (Antinuclear Antibody ANA. Anti-double-stranded DNA [ dsDNA ], C3, C4 were done byimmunological method), SLE with LN (biopsy approved) patients. Using (5ml) disposable syringe between (8.30-12) AM, five $\mathrm{ml}$ of venous blood was taken from subjects. Four mlfrom the sample was transferred to the sterile plain tube enable to clotted and then centrifuged for $15 \mathrm{~min}$ at $3000 \mathrm{rpm}$.

Serum was dispensed in several aliquots and frozen at $-20{ }^{\circ} \mathrm{c}$ immediately before analyzed the immunological and biochemical markers (Urea, total protein, Creatinine, C3,C4, Anit ds DNA, ANA and h-CRP by enzymatic and immunoturbidity method. The remaining blood samples $(1 \mathrm{ml})$ were transferred to EDTA tubes for hematological analysis(ESR). SVCAM-1 and IL-18 analyzed in the kit use enzyme-linked immune sorbent assay (ELISA) based on biotin double antibody sandwich technology.

Statistical Analysis: The system-SAS (2012) software for statistical analysis was used to detect the effect of differentiating factors on the study parameters. The least significant difference - the LSD test (Analysis of Variation-ANOVA) was used to make a significant comparison between the means. To significantly compare the percentage ( 0.05 and 0.01 probability), the chi-square test was used. Estimation of the coefficient of correlation between variables of difference in this study. ${ }^{(11)}$

\section{Results}

Table 1 shows mean \pm SD values for age, BMI, duration of SLE, urea, creatinine, total protein, Albumin C3, C4, ANA, Anti ds DNA, ESR and h-CRP. The results showed significant differences of age for the studied groups ( $p>0.01)$, while a significant increase in the body mass index (BMI),blood urea (BU), creatinine (Cr), ANA, Anti-ds DNA, ESR and h-CRP in groups of patients(SLE with LN, SLE without LN) were observed in comparison with control. In contrast, there was a significant decrease in total protein, Albumin C3, C4 in patient groups compared to healthy subjects. 
Table 1: Clinical chartists "mean \pm SD values for age, BMI, duration of SLE, urea, creatinine, total protein, Albumin C3, C4, ANA, Anti ds DNA, ESR and h-CRP"

\begin{tabular}{|c|c|c|c|c|}
\hline \multirow{2}{*}{ Factors } & \multicolumn{3}{|c|}{ Mean $\pm \mathrm{SE}$} & \multirow{2}{*}{ LSD value } \\
\hline & Control & SLE without nephrites & SLE with nephrites & \\
\hline Age (year) & $41.02 \pm 2.01 \mathrm{a}$ & $29.37 \pm 1.25 \mathrm{~b}$ & $31.05 \pm 1.33 \mathrm{~b}$ & $4.400 * *$ \\
\hline BMI $\left(\mathrm{kg} / \mathrm{m}^{2}\right)$ & $26.94 \pm 0.40 \mathrm{~b}$ & $28.54 \pm 0.49 \mathrm{a}$ & $29.56 \pm 0.61 \mathrm{a}$ & $1.438 * *$ \\
\hline Duration (year) & --- & $3.63 \pm 0.19 b$ & $6.11 \pm 0.26 \mathrm{a}$ & $0.657 * *$ \\
\hline Urea (mg/dl) & $23.47 \pm 0.88 \mathrm{c}$ & $31.08 \pm 0.63 b$ & $57.98 \pm 1.06 \mathrm{a}$ & $2.45 * *$ \\
\hline Total protein $(\mathrm{mg} / \mathrm{dl})$ & $7.05 \pm 0.17 \mathrm{a}$ & $6.66 \pm 0.08 b$ & $6.50 \pm 0.08 b$ & $0.348 * *$ \\
\hline Creatinine (mg/dl) & $0.815 \pm 0.04 \mathrm{~b}$ & $0.887 \pm 0.03 \mathrm{~b}$ & $1.785 \pm 0.06 \mathrm{a}$ & $0.139 * *$ \\
\hline $\mathrm{C} 3(\mathrm{mg} / \mathrm{dl})$ & $161.56 \pm 5.13 \mathrm{a}$ & $90.81 \pm 1.38 b$ & $80.55 \pm 1.33 \mathrm{c}$ & $8.86 * *$ \\
\hline $\mathrm{C} 4(\mathrm{mg} / \mathrm{dl})$ & $47.96 \pm 3.10 \mathrm{a}$ & $23.23 \pm 0.46 b$ & $25.03 \pm 0.78 b$ & $5.23 * *$ \\
\hline AnitdDNA (IU/ml) & $10.66 \pm 0.90 \mathrm{c}$ & $60.23 \pm 1.39 b$ & $75.48 \pm 2.37 \mathrm{a}$ & $4.68 * *$ \\
\hline ANA (IU/ml) & $1.264 \pm 0.80 \mathrm{c}$ & $7.45 \pm 0.34 b$ & $19.01 \pm 1.07 \mathrm{a}$ & $2.24 * *$ \\
\hline h-CRP (mg/l) & $1.800 \pm 0.15 \mathrm{c}$ & $9.32 \pm 0.22 \mathrm{~b}$ & $15.14 \pm 0.60 \mathrm{a}$ & $1.077 * *$ \\
\hline $\operatorname{ESR}(\mathrm{mm} / \mathrm{h})$ & $4.88 \pm 0.21 \mathrm{c}$ & $47.09 \pm 0.85 b$ & $57.84 \pm 1.22 \mathrm{a}$ & $2.44 * *$ \\
\hline
\end{tabular}

Table (2) shows a comparison between inflammation markers sVCAM and IL18 for the studied groups which are revealed significant correlation depending on the disease case compared healthy case $(\mathrm{p}<0.01)$

Table 2: Comparison between inflammation markers for the studied groups

\begin{tabular}{|l|c|c|c|c|}
\hline \multirow{2}{*}{ Parameters } & \multicolumn{3}{|c|}{ Mean \pm SE } & \multirow{2}{*}{ LSD value } \\
\cline { 2 - 5 } & SLE without nephrites & SLE with nephrites & Control & $2.26 * *$ \\
\hline sVCAM $(\mathrm{ng} / \mathrm{ml})$ & $3.22 \pm 0.42 \mathrm{~b}$ & $8.37 \pm 1.32 \mathrm{a}$ & $1.52 \pm 0.18 \mathrm{~b}$ & $2.25 * *$ \\
\hline $\mathrm{IL}-18(\mathrm{~g} / \mathrm{ml})$ & $3.78 \pm 0.38 \mathrm{~b}$ & $8.96 \pm 1.34 \mathrm{a}$ & $1.11 \pm 0.13 \mathrm{c}$ & 2 \\
\hline
\end{tabular}

$* *(\mathrm{P}<0.01)$.

The study revealed that a significant correlation was found between sVCAM and IL18 $\left(\mathrm{r}=0.45^{*}\right)$, while there is no correlation found between others parameters, as shown in figure 1 .

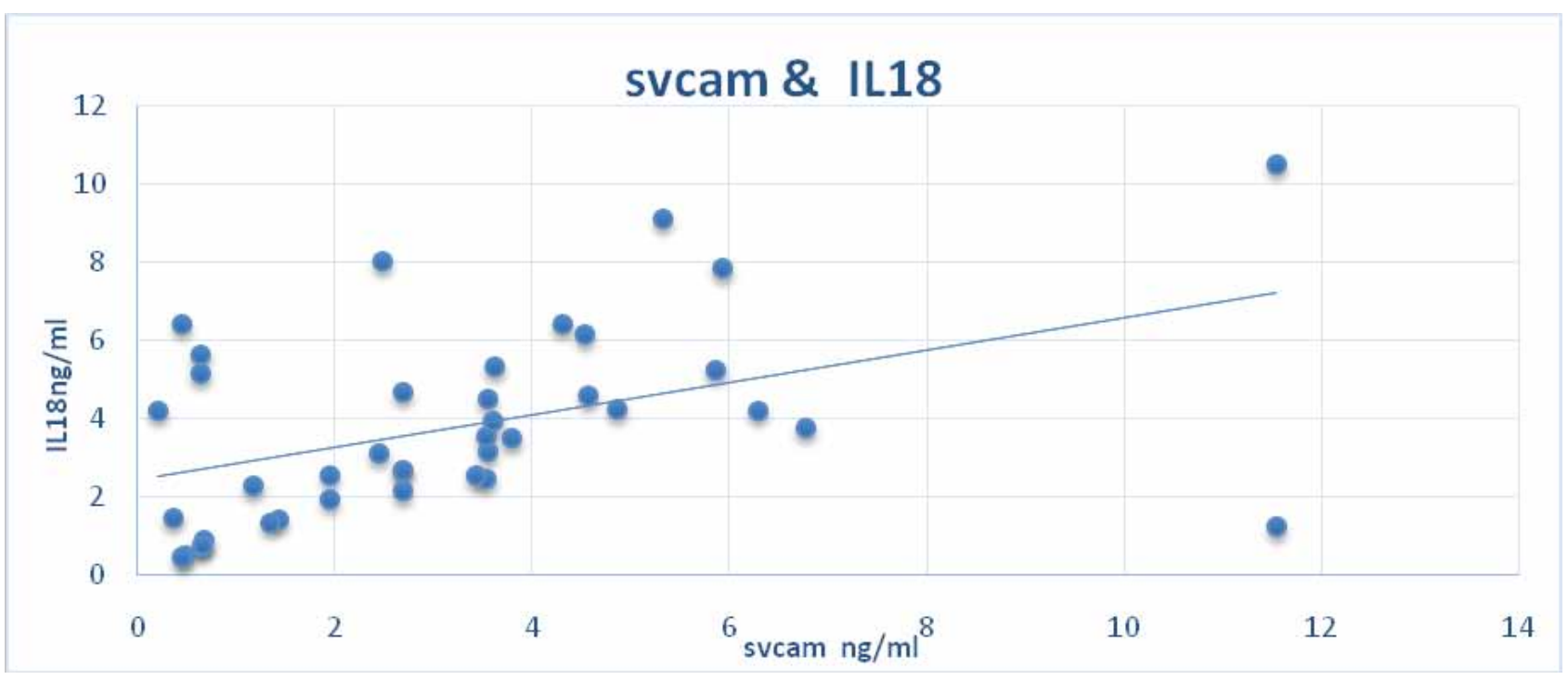

Figure (1): The correlation between IL18 and sVCAM 
The study was found that serums VCAM, IL-18 levels in patients group without nephrites showed no correlation with other parameters as indicated in table (3).

Table 3: shows correlation between sVCAM, IL-18 and biochemical parameters in SLE patients without nephrites.

\begin{tabular}{|l|c|c|c|c|}
\hline \multirow{2}{*}{ Parameters } & \multicolumn{2}{|c|}{ sVCAM } & I & P18 \\
\cline { 2 - 5 } & $\mathbf{r}$ & 0.627 & 0.04 & 0.805 \\
\hline Age & -0.07 & 0.523 & 0.05 & 0.772 \\
\hline BMI & -0.10 & 0.392 & -0.06 & 0.686 \\
\hline Urea & -0.13 & 0.08 & 0.09 & 0.544 \\
\hline Treatinine & 0.27 & 0.135 & -0.07 & 0.627 \\
\hline Albumin & -0.24 & 0.697 & 0.02 & 0.884 \\
\hline h-CRP & -0.06 & 0.697 & 0.14 & 0.384 \\
\hline ESR & -0.06 & 0.034 & -0.23 & 0.136 \\
\hline C3 & -0.33 & 0.861 & -0.05 & 0.756 \\
\hline C4 & 0.03 & 0.006 & -0.28 & 0.072 \\
\hline Anti ds DNA & -0.42 & 0.189 & -0.26 & 0.102 \\
\hline ANA & -0.21 & 0.741 & -0.03 & 0.857 \\
\hline
\end{tabular}

* (P: 0.01-0.05), ** (P: less than 0.01), NS (P: More than 0.05).

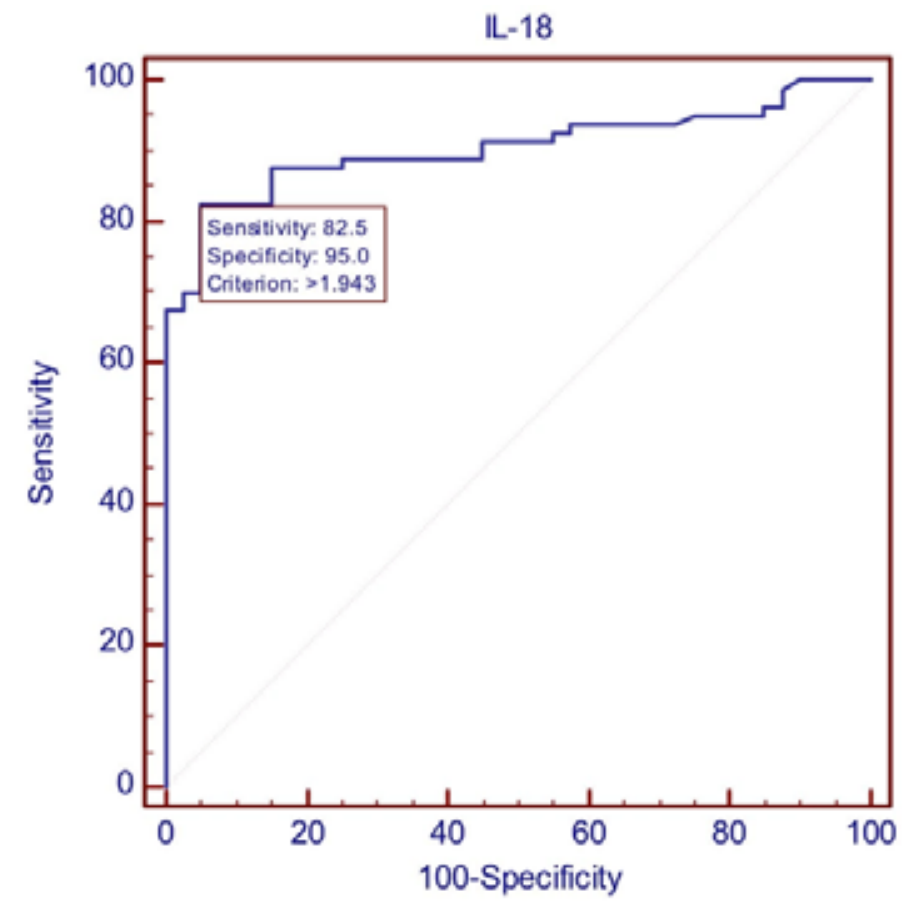

Figure (2): The Roc curve for IL18

Area under the ROC curve (AUC) for the analysis includes IL18 is (0.904). The best cut-off point derived from the ROC curve shows a sensitivity of (82.5\%) and specificity of $(95.0 \%)$ is $\leq 1.943(\mathrm{ng} / \mathrm{ml})$. A test value below $1.943(\mathrm{ng} / \mathrm{ml})$ is referring to the abnormal case (disease case) and the value above $1.943(\mathrm{ng} / \mathrm{ml})$ is representing the healthy case. As shown in figure (2), a high significance difference is $(\mathrm{P}<0.0001)$. 
sVCAMtest is considered good marker to diagnose SLE because area under the ROC curve (AUC) for the analysis is (0.754). The best cut-off point derived from the ROC curve shows a sensitivity of $(66.2 \%)$ and specificity of $(77.5 \%)$ is $\leq 2.232(\mathrm{ng} / \mathrm{ml})$. A test value below $2.232(\mathrm{ng} / \mathrm{ml})$ is referring to the abnormal case (disease case) and the value above $2.232(\mathrm{ng} / \mathrm{ml})$ is representing the healthy case. As shown in figure (3), a high significance difference is $(\mathrm{P}<0.0001)$.

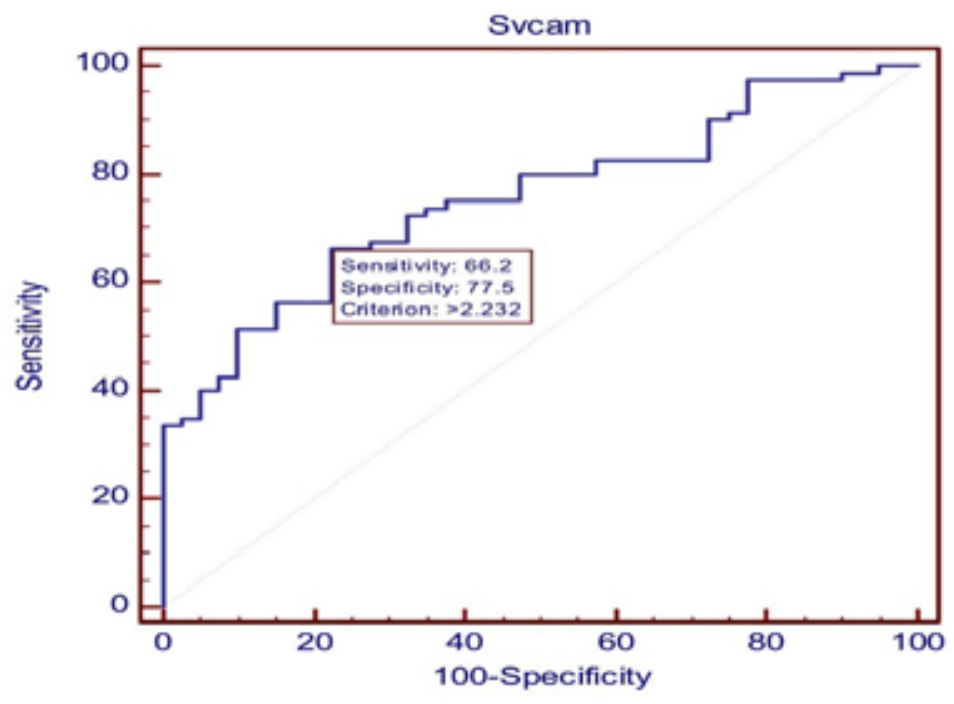

Figure (3): The Roc curve for SVCAM

\section{Discussion}

VCAMis associated with inflammatory cell sequestration through interactions with leucocyte integrated integrin. Soluble VCAM-1leveles are raised in several autoimmune diseases, including rheumatoid arthritis and $\mathrm{SLE}^{(12)}$.

Earlier studies showed the serum concertation Svcam-1 control the development of SLE disease ${ }^{(13)}$. Conforming to these previous studies, it was found that absolute SVCAM-1 levels were less useful than other traditional markers such as ds DNA anti body titers C3 and $\mathrm{C} 4$ levels as a diagnostic tool for the identification of SLE patients due to the inherent variation of SVCAM-1 levels between individuals. ${ }^{(14)}$

In past years, it was reported that sVCAM-1 level may be associated with endothelial activation. In general sVCAM and sICAM serum concertation in coronary artery disease and endothelial dysfunction - related disease are only modestly evaluated. This complies with evidence that sICAM-1 levels are nearer to systematic endothelial dysfunction than sVCAM-1 levels. sVCAM-1 level is related with those observed in patients with necrotic shock ${ }^{(15)}$.

Patients with elevated SLE disease activity are among the most significant. Our observation that sVCAM-1 level are much stronger than sICAM-1, sP-selectin, sE- selectin, shows variances in the level sVCAM-1 reflect other physiological roles than endothelial activation. Furthermore, Vcam-1 has a major role at several essential steps of lymphocyte production due to its pervasive expression in minor lymphoid tissues $^{(16)}$.

VCAM-1 is largely expressed in bone marrow stream cells and is required for both early pre-pro Bcell production and long- lived bone marrow plasma cell retention. B-cell maturation in the mouse is caused by conditional of VCAM-1, which lead to increased circulating immature B-cell, suggesting that VCAM-1is an important factor for homing mature $\mathrm{B}$ bone marrow cells. ${ }^{(17)}$

It is not clear if sVCAM-1 is eliminated in the course of any the cell interactions between lymphocytes 
and DC or other stromal cells that have VCAM-1. The super family IL-1 is made up of 11 members; some are known to be pro-inflammatory, including IL-1 $\alpha$, IL-1 $\beta$ and IL-18, the most studied IL-1 superfamily members in autoimmune disease, all of whom have been involved in SLE pathogenesis. ${ }^{(18)}$

In this research, we demonstrated that serum IL18 levels are considerably higher in patients with SLE. These results confirm previous studies that there are significantly higher IL18 levels in SLE patients than healthy control (19)

The association of IL18 with an overall active disease (ODA) is reported in previous studies, like kidney disease and organ damage, related to other variables and also in patients with biopsy-proven LN. The association of IL-18 with active renal disease was confirmed. Similarly, in LN patients, an earlier study has shown elevated serum IL-18 levels ${ }^{(20)}$.In other studies in both glomeruli and LN cases, it was found an increase in IL-18. IL-18 has also been proposed as a suitable marker for long term outcomes in pediatric LN.Kidney dysfunction is a significant indictor of SLE harm development; previous results in smaller study documenting revealed the elevated IL-18 level in patients with organ damage ${ }^{(21)}$.

Acknowledgments: We would like to thank the staff of the Baghdad Teaching Hospital in the Medical City, and department of chemistry in College of Science for Women, University of Baghdad for their efforts and supports that helped to conduct this study.

Ethical Clearance: The Research Ethical Committee at scientific research by ethical approval of both MOH and MOHSER in Iraq.

\section{Conflict of Interest: Non}

Funding: Self-funding

\section{References}

1. Choubey D, Panchanathan R. Absent in Melanoma 2 proteins in SLE. Clinical immunology (Orlando, Fla.) .2017;176:42-48.

2. Kadhim K. G. Effect of alcoholic catechin extract on hyperglycemia, hyperlipidemia and liver functions in alloxan -diabetic mice. Baghdad Sci. J. 2014;11 :3: 1192-1200.

3. Kadhim K. G, Kismat M. T., Sabreen A. M., Gaze
T. A. and Mohammed H. A. 2 Association of Serum Adiponectin with Serum Insulin and Body mass density (BMD) in postmenopausal Osteoporotic women with and without T2DM. IOSR. Journal of Applied Chemistry (IOSR-JAC).2014; 7 (5): 119122

4. Springer TA. Traffic signals for lymphocyte recirculation and leukocyte emigration: the multistep paradigm. Cell. 1994;76:301-14.

5. Pigott R, Dillon LP, Hemingway IH, Gearing AJ. Soluble forms of E-selectin, ICAM-1 and VCAM-1 are present in the supernatants of cytokine activated cultured endothelial cells. BiochemBiophys Res Commun. 1992;187:584-9.

6. Janssen BA, Luqmani RA, Gordon C, Hemingway $\mathrm{IH}$, Bacon PA, Gearing AJ, et al. Correlation of blood levels of soluble vascular cell adhesion molecule-1 with disease activity in systemic lupus erythematosus and vasculitis. $\mathrm{Br} \mathrm{J}$ Rheumatol. 1994;33:1112-6

7. Spronk PE, Bootsma H, Huitema MG, Limburg PC, Kallenberg CG. Levels of soluble VCAM1, soluble ICAM-1, and soluble E-selectin during disease exacerbations in patients with systemic lupus erythematosus (SLE); a long term prospective study. Clin Exp Immunol. 1994;97:439-44.

8. Ikeda Y, Fujimoto T, Ameno M, Shiiki H, Dohi K. Relationship between lupus nephritis activity and the serum level of soluble VCAM-1. Lupus. 1998;7:347-54.

9. Wu T, Xie C, Wang HW, Zhou XJ, Schwartz $\mathrm{N}$, Calixto $\mathrm{S}$, et al. Elevated urinary VCAM-1, P-selectin, soluble TNF receptor-1, and CXC chemokine ligand 16 in multiple murine lupus strains and human lupus nephritis. J Immunol. 2007;179:7166-75.

10. Singh S, Wu T, Xie C, Vanarsa K, Han J, Mahajan $\mathrm{T}$, et al. Urine VCAM-1 as a marker of renal pathology activity index in lupus nephritis. Arthritis Res Ther. 2012;14:R164

11. Kaplanski G, Cacoub P, Farnarier C, Marin V, Gregoire R, Gatel A, et al. Increased soluble vascular cell adhesion molecule 1 concentrations in patients with primary or systemic lupus erythematosusrelated antiphospholipid syndrome: correlations with the severity of thrombosis. Arthritis Rheum. 2000;43:55-64.

12. Wu C-Y, Yang H-Y, Yao T-C, Liu S-H, Huang 
J-L. Serum IL-18 as biomarker in predicting longterm renal outcome among pediatric-onset systemic lupus erythematosus patients. Medicine .2016; 95:e5037.10.

13. Brugos B, Vincze Z, Sipka S, Szegedi G, Zeher M. Serum and urinary cytokine levels of SLE patients. Pharmazie .2012; 67:411-3.

14. Dinarello CA, Novick D, Kim S, Kaplanski G. Interleukin-18 and IL-18 binding protein. Front Immunol .2013; 4:289.10.3389

15. Hoshino T, Kawase Y, Okamoto M, Yokota K, Yoshino K, Yamamura K, et al. Cutting edge: IL18-transgenic mice: in vivo evidence of a broad role for IL-18 in modulating immune function. J Immunol .2001;166:7014-8.10

16. Wasnaa j. M., Basim S., Nizar Ab.j. and Mohammed Sh. J. Validity of $\mathrm{Cd} 4$ enhancer gene polymorphism in suscebtibility and severity of some Iraqi rheumatoid arthritis patients. IJAR 2016; 3,1200-1205.
17. Perry D, Sang A, Yin Y, Zheng Y-Y, Morel L. Murine models of systemic lupus erythematosus. J Biomed Biotechnol .2011; 271694.10.1155

18. Schirmer B, Wedekind D, Glage S, Neumann D. Deletion of IL-18 expression ameliorates spontaneous kidney failure in MRLlpr mice. PLoS One .2015; 10:e0140173.10.1371/journal. pone. 0140173

19. Jafari-Nakhjavani MR, Abedi-Azar S, Nejati B. Correlation of plasma interleukin-18 concentration and severity of renal involvement and disease activity in systemic lupus erythematosus. Journal of nephropathology. 2016;5:28-33.

20. Gross O, Thomas CJ, Guarda G, Tschopp J. The inflammasome: an integrated view. Immunological reviews. 2011;243:136-151. doi: 10.1111/j.1600065X.2011.01046.X

21. Validity of TNFR II polymorphism in susceptibility and severity of rheumatoid arthritis Iraqi patients. Int.J.curr.microbiol.App.sci .2016. 5(5):969-975. 